thinner under the dissolving or digesting action of the leucocytes. The congestion in the uterus and vagina becomes still more pronounced, giving rise to small blood masses or hæmatomata beneath the epithelium. The epithelium of the uterus is highly disorganized, vacuolized and richly invaded by the leucocytes, so that portions of it fall away en masse, actually carrying with it in some cases cells of the stroma.

(d) The fourth stage is merely a continuation or result of the activities of the third. The falling away of the epithelial pieces and stroma cells permits the escape of the small hæmatomata or blood knots, thus causing a slight bleeding into the lumen of the uterus and vagina. These traces of blood often give a reddish aspect to the vaginal fluid. At this same stage a regeneration process begins from the necks of the uterine glands and also apparently from the epithelial infoldings in the vagina, so that the lost epithelium becomes rapidly replaced almost before it has ceased falling away.

The regeneration process in the guinea-pig is very short, lasting only a few hours, from six to twelve in all.

Orulation seems to occur spontaneously during every heat period without exception. The rupture of the follicles with the consequent ovulation takes place about the end of the second stage or the beginning of the third; that is, during the presence of the thick cheese-like vaginal fluid.

During the diœstrum or intermenstrual period there is very little fluid to be found in the vagina. This scant fluid consists of mucus in which are some atypical squamous cells from the vaginal wall and many leucocytes. A number of the leucocytes are old but there are probably new ones arriving almost continuously from the wall of the vagina. The only time at which the vagina seems to be practically free of leucocytes is immediately before and during the first and second stages of the ostrous period described above.

A marked correlation exists between the œestrous changes in the uterus and the developmental cycle of the corpora lutea. When the corpora lutea are highly developed and apparently active the mucosæ of the uterus and vagina show a normally vigorous and healthy condition. While on the other hand, when the corpora lutea begin to degenerate during the second week after the "heat period" the mucosæ of the uterus and vagina also begin to shown signs of degeneration and the process of desquamation slowly commences. At about two weeks after the last "heat period," when the wholesale destruction of the mucosa begins, the corpora lutea are almost completely degenerated. The breaking of the Graafian follicles occurs during the œstrus as a result of a congestion which began in the theca folliculi at about the same time as the congestion of the stroma of the uterus and vagina. And finally when the regenerative growth of the uterine mucosa sets in, the ovaries then possess new corpora lutea in an active state of differentiation which were derived from the recently ruptured follicles.

It, therefore, might be imagined that the secretion from the corpora lutea exerts a protective influence over the uterus and vagina while the absence of this secretion permits the breaking down and degeneration of the uterine epithelium typical of the "heat period."

C. R. STOOKaRd,

G. N. Papanicolaou

\section{THE IOWA ACADEMY OF SCIENCE}

THE thirty-first annual session of the Iowa Academy of Science was held at Grinnell College, Grinnell, on April 27 and 28. The opening meeting was called to order on Friday afternoon by President Stewart, of the State University. After the transaction of preliminary business the president delivered his annual address on "Recent advances in physical science and the relation of the Iowa Academy to scientific progress." Professor Conard, of Grinnell, who had been the academy's delegate to the tenth annual meeting of the Illinois Academy of Science, gave a report of that meeting. A number of papers of general interest were read and the president announced that other papers would be read before the appropriate sections, which were: 1, Geology; 2, Zoology and Botany; 3, Mathematics, Physics and Chemistry.

Professor R. A. Millikan, of the University of Chicago, was to have given the annual address, but 
as he was unable to leave his work on the Council for National Defense, at Washington, Professor $\mathbf{S}$. M. Woodward, of the University of Iowa, gave the address on the "Application of science to flood prevention," an outline of his work on the Dayton, Ohio, flood-prevention project.

Following the meetings of the sections on Saturday morning the business meeting was held, at which the following officers were elected for the coming year.

President-L. S. Ross, Drake University, Des Moines.

First Vice-president-S. W. Beyer, State College, Ames.

Second Vice-president-C. E. Seashore, State University, Iowa City.

Secretary-James H. Lees, Iowa Geological Survey, Des Moines.

Treasurer-A. O. Thomas, State University, Iowa City.

Resolutions were adopted pledging the support of the academy to the President of the United States, also commending the action of the Iowa legislature in passing laws to give quail and prairie chicken a closed season of five years and providing for a board of conservation to investigate localities in Iowa which are of scenic, scientific and historic interest.

PROGRAM

Geology and Allied Subjects

$A$ notable mound group near the proposed government park at McGregor: ELLISON ORR.

(a) Wave action and results of ice action as seen near the Macbride Lakeside laboratory, summer of 1916. (b) Second record of oscillations in lake level, and records of lake temperatures and meteorology, at the Macbride Lakeside laboratory, July, 1916 : JoHN L. TILTON.

Possible fan structure in Canadian Rockies: Charles Keyes.

The Cordillera in Jasper Park, in northwest Alberta, as in other parts of the great mountain chain, is characterized by tremendous thrust planes; but unlike most other portions there is on the east flank a sharp flexing on a large scale. The especially notable feature is the Appalachian or Alpine type of structure. The relationships of the various members are presented with greater perspicuity than anywhere else throughout the entire extent of the Rocky Mountain region, perhaps with greater graphic distinctness than Appalachian structure is exhibited in the whole world. A hundred miles farther south, on the west side of the chain, the pre-Cambrian clastics with steep but variable slants indicate the presence of the other half of the orographic fan.

Glacier dams of central Washington: CHARLES KEYES.

Extent and age of Cap-au-Gres fault: CharLes KEYES.

$A$ bibliography of the driftless area: W. D. SHIPTON.

(a) The Iowan glaciation and the so-called Iowan loess deposits. (b) Post-Kansan erosion. (c) The Buchanan gravels of Calvin and the Iowan outwash: M. M. LEIGHTON.

The loess and the antiquity of man: B. SHIMER.

History of the Pleistocene in Iowa: EMMET J. Cable.

Pleistocene deposits between Manilla in Crawford county and Coon Rapids in Carroll county, Iowa: George F. KaY.

The most significant features that have been revealed by a study of the Pleistocene deposits in many deep cuts made recently between Manilla in Crawford county and Coon Rapids in Carroll county, by the Chicago, Milwaukee and St. Paul Railway Company, were described.

Ocheyedan mound, Osceola county, Iowa: George F. KAY.

This brief paper describes the chief characters of the long time famous Ocheyedan mound, which is thought by many persons to be the most picturesque topographic feature in northwestern Iowa.

The mound is a kame which was formed during the recession of the Wisconsin ice sheet.

The esthetic value of such beautiful and interesting geological phenomena as Ocheyedan mound should be fully appreciated by the citizens of the state, and every effort should be made to prevent their destruction. Already Ocheyedan mound has been somewhat marred by the removal at its summit of sand and gravel which was used for commercial purposes. To be sure, the mound is valuable for the many thousands of tons of material that might be taken from it to be used for roadmaking or other purposes, but of far greater value is it to the state as a beauty spot, a landmark, which should be conserved for future generations just as zealously as we are wont to conserve our material resources.

$A$ note regarding a slight earthquake at Iowa City, on April 9, 1917: GroRge F. KAY.

$A$ supposed fruit or nut from the Tertiary of Alaska: A. O. Thomas. 
The specimen, which was collected in the coalbearing beds of the Tokun formation, is about 8 $\mathrm{cm}$. in diameter. The symmetrical arrangement of certain meridional and other lines on its surface and attached fragments of what appears to have been an epicarp suggest that it may be a fossil fruit or nut. Other possibilities are suggested.

\section{A large colony of fossil coral: A. O. THomas.}

A coral colony of gigantic proportions was recently discovered in a reef of Niagaran corals in Jones county. Conditions under which the colony occurs, its dimensions and associations, are described. Illustrations.

Notes on a decapod Crustacean from the Kinderhook shale near Burlington: OTTO WALTER.

Mississippian erustaceans are comparatively rare. An incomplete specimen found imbedded in a hard shaly nodule is described. It seems to be allied to the old genus Paleopaleomon.

Some observations on the history of Yangtse River, China: C. L. Foster.

Some geologic aspects of conservation: JAMES $\mathrm{H}$. LEES.

Some of the beauty spots of Iowa are described and their scenic and geologic values are mentioned. The necessity for their preservation is emphasized.

Some fundamental concepts of earth history: JAMES H. Lees.

After a brief discussion of the evidence for progressive development of the material world there is given an outline of the trend of thought regarding the history of the earth. This outline covers the work of leading thinkers from the Greek and Roman philosophers to the great systems evolved by La Place and Chamberlin.

(a) The Prairie du Chien-St. Peter unconformity in Iowa. (b) The origin of the St. Peter sandstone. (c) Some conclusions concerning the erosional history of the ariftless area: A. C. Trowbridge.

\section{Home Economics}

Improved method for home canning: C. N. KINNEY AND MAURICE Ricker.

Suggested use of calcium chloride and other salts in solution in outer vessels of double boilers to raise boiling point in inner vessel.

Experiments in cooking cereảls, canning fruit and vegetables indicate that this cheaper device may replace the auto-clav for these purposes, especially when the inner vessel is subjected to slight pressure.

\section{Physics}

(a) Certain features of rheostat design. (b) $\Delta n$ interesting case of resonance in an alternating current circuit: H. L. DoDGE.

The absence of relationship between electro-mechanical properties of selenium crystals and their photo-electric emission by ultra-violet light: F. C. BRown AND F. S. YeTter.

The $X$-ray $\boldsymbol{K}$-radiation from tungsten: ELMER DERSHEM.

The influence of intensity ratio in binaural sound localization: E. M. BERRY AND C. C. BuNCH.

$A$ peculiar electrically conducting layer on the surface of mica: G. W. STEWART.

On the torsional elasticity of drawn tungsten wires: L. P. SIEG.

The thermal conductivity of tellurium: ARTHUR R. FORTSCH.

(a) Electrical capacity of similar, non-parallel plane plates, and its application where the plates are non-rectangular. (b) Mathematics of stroboscopy; The strobodeik; Theory of the stroboscopic effect by reflection of light from vibrating mirrors. (c) Precontact conduction currents: L. E. DoDD.

Effect of drawing on the density and specific resistance of tungsten: WM. ScHRIEvER.

Effect of gases on unilateral conductivity: ROBERT B. Dodson.

\section{Zoology and Allied Subjects}

Birds of the past winter, 1916-1\%, in northwestern Iowa: T. C. Stephens.

$A$ list of the birds observed in Clay and O'Brien counties, Iowa: IRA N. GABRIELSON.

An annotated list of the mammals of Sac county, Iowa: J. A. SPURRELL.

Bell's vireo studies: WALter W. BeNNETT. (Illustrated with lantern.)

Observations on Bell's vireo, a species of the central United States which has heretofore been little studied. Near Sioux City it arrives unobtrusively from the south during the second and third weeks in May. During nesting, which immediately follows, the bird has been found to sing on the nest after the fashion of the warbling vireo. A tendency of the bird to become easily tamed, a habit of very frequently sitting for long periods in a resting attitude near the nest, and other characteristic actions have been noted. Also, an un. usually large proportion of cowbird's eggs in their nests and other facts point to a possible diminishing number of individuals of the species, at least near Sioux City. 
An analysis of the cranial ganglia in Squalus acanthias: SALLY P. HUGHES. (Illustrated with lantern.)

This analysis confirms the results of Strong (1903) and Landacre (1916). The trigeminus ganglion is constricted into a ventral maxillaris and a dorsal mandibular and superficial ophthalmic portion; the ophthalmicus profundus has a distinct ganglion. The facialis comprises the geniculate ganglion, a motor root distributed through the hyomandibular trunk, and three lateral line ganglia-a buccal, a superficial ophthalmic VII., and a third out in the hyomandibular trunk-the fibers from the last two forming the dorsal lateral line root, those from the buccal, the ventral. The auditory ganglion is distinct, rising by a large root just ventral and posterior to the lateral line roots of the VII. The IX. ganglion is visceral sensory with a small lateral line ganglion in its anterior end. The lateral line fibers rise by a small separate root just barely in contact dorsally with the lateral line root of the $X$. The vagus rises by a large anterior lateral line root followed by a succession of visceral sensory and motor roots. There are three lateral line ganglia on the $X$., almost fused together. A small general cutaneous element is given off with fibers from the first two of these. The visceral ganglia are also slightly segmented into four branchial and one intestinal portion, the last two quite inseparable. The cervical plexus, comprising the two occipitals and first three spinal nerves, is in contact with the vagus, but entirely distinet from it.

The eyeball and associated structures in the blindworms: H. W. NoRRIs. (Illustrated with lantern.)

The optical apparatus in the Cœcilians undergoes various degrees of degeneration and transformation, from a condition where the entire mechanism is present, but in a rudimentary condition, to that where only a vestigial eyeball and much modified and transformed retractor and levator bulbi muscle are present.

Bermuda as a type collecting ground for invertebrates: H. A. CRoss, JR.

White grub outbreaks in northeastern Iowa: R. L. WEBSTER.

A brief account of the destructive outbreaks of white grubs in northeastern Iowa in 1912 and 1915; the relation of the contour of the land and the abundance of timber to these outbreaks; the prospects for damage in the near future.
The influence of the male on litter size: EDWARD N. WENTWORTH.

Entomostraca of northwestern Iowa: F. A. STROMSTEN.

The following is a list of Entomostraca collected in the neighborhood of the Macbride Lakeside Laboratory, Lake Okoboji, Iowa, during August, 1916: Sida crystallina, Daphnia hyalina, Daphnia kahlbergensis, Daphnia Scapholebris mucronata, Simocephalus vetulus, Simocephalus serrulatus, S. americana, Bosmina longirostris, Camptocercus macrurus, Alonella excisa, Pleuroxus stramineus, $P$. hamatus, $P$. denticulatus, $P$. procurvus, Diaptomus sicilis, D. signicauda, $D$. oregonensis, D. clavipes, D. pallidus, Cyclops signatus var. coronatus, C. $s$. var. tenucornis, C. insignis, C. serrulatus, C. macrurus, C. fuviatilis, C. affinis, C. bicolor, C. phaleratus, C. fimbriatus.

The development of the musk gland in the loggerhead turtle: Frank A. Stromsten.

Some new endoparasites of the snake: ThesLe T. JoB.

Porocephalus globicephalus Hett; the characters of the male, which Hett did not have in describing the species, are recorded and additional notes on the habits and anatomy of both sexes offered.

A distome, Renifer $s p$ ?, closely allied to $R$. ellipticus Pratt. Measurements of the specimens recorded.

Larvæ of Acanthocephalia, Gigantorynchus sp?, larval condition described.

Further notes on the venous connections of the lymphatic system in the common rat: THasLe $\mathrm{T}$. Joв.

In addition to the portal, renal and ilio-lumbar vein communications reported in 1915, an inferior vena caval communication at the level of the lumbar nodes has been demonstrated. The variable occurrence of the communications and the lack of correlation of these taps is shown. The possible effect of the physiological condition of the animals and of the injecting technic on the demonstration of the communications is suggested. Conclusions as to the significance of the communications are delayed until the embryological study now in progress is completed.

Mites affecting the poison oate: H. E. EwING.

The Odonata of Iowa: LLOXD WeLLS.

Observations on the Protozoa, with descriptions and drawings of some probable new species: Clementina S. SPencer.

Notes on some Iowa rodents: DAYTON STONER.

A brief progress report of some work now under 
way on the rodents of Iowa for the Iowa Geological Survey. Two forms, Sciurus hudsonicus minnesota Allen and Lepus californicus melanotis Mearns, are for the first time recorded from Iowa and the known distribution of some other species of rodents is extended. A brief survey of the bounty system in the state is also given.

\section{Botany}

The Sand-flora of Iowa: B. SHImer.

Some additional notes on the pollination of red clover: L. H. PAMMeL AND L. A. KenOYer.

The germination and juvenile forms of some oaks: L. H. Pammel and Charlotie M. King.

Plant studies in Lyon county, Iowa: D. H. Boot.

Notes on Melilotus alba: WALTER E. RoGERS.

The cleistogamy of Heteranthera dubia: $\mathbf{R}$. B. WrIIE.

The infuence of soil management on the formation and development of fruit buds: R. S. KIRBY.

(a) The white waterlily of Clear Lake, Iowa. (b) Tree growth in the vicinity of Grinnell, Iowa: H. S. CONARD.

$A$ picea from the glacial drift: WmBUR $\mathrm{H}$. Thomas.

Pioneer plants on a new levee, III.: FraNK E. A. THONE.

The morphology of the thallus and cupules of Blasia pusilla: MARguerite B. ROHRET.

Chlorotic corn: W. H. Davis.

The acial stage of alsike clover rust: W. H. DAvis. The rusts on clover were formerly classified as one species until Liro proved the rust on white clover (T. repens L.) separate, autœcious and possessing all spore forms. The reial stage of red clover rust was definitely described by Davis and Johnson at a meeting of the American Association for the Advancement of Science, December, 1916. They showed this rust to be autœcious also, and composed of all spore forms. The disposition of the rust on alsike clover has not been clear; some place it with red clover rust while it is generally regarded as white clover rust. The acial stage has not been reported in the United States, but has been reported in Germany by Rostrup (1888). The correct determination of his host is not generally accepted.

The use of ferric and ferrous phosphate in nutrient solutions: GEORGE E. CoRsON AND ARTHUR L. BAKKE.

A series of experiments have been performed using varying amounts of ferrous and ferric phos- phate in Shive's solution as a general basis, in the growth of wheat and Canada field pea seedlings. Ferrous phosphate can not replace the ferric phosphate. The amount as used by Shive has been determined to be the best for the growth of wheat, but for Canada field pea the iron requirement is evidently higher.

\section{Chemistry}

(a) Some natural waters of central New York. (b) Diffusion phenomena of double salts: NIOHOLAS KNIGHT.

Water-works laboratories: JACK J. HINMAN, JR.

A collection of data from ninety water works laboratories in the United States and Canada, safeguarding an average daily supply of $2,800,000$,000 gallons for more than $17,000,000$ people. All of these laboratories have been established since 1897. Their organization and methods of chemical and bacteriological control are discussed from the technical standpoint.

Laboratory control is essential to the proper operation of water-works plants which treat a water of variable character.

The free energy of dilution of lithium chloride in aqueous and alcoholic solutions by the electromotive force method: F. S. MoRTIMER AND J. N. Pearce.

The electrical conductivity and viscosity of solutions of silver nitrate in pyridine: H. L. DUNLAP AND J. N. Pearce.

$A$ study of the relation between solubility, the heat of solution and the properties of the solvent: $\mathrm{H}$. E. Fowler and J. N. PEarce.

The partial analyses of some Iowa clays (preliminary report) : J. N. PeARCE.

The protein content and microchemical tests of the seeds of some common Iowa weeds: L. H. PAMMEL AND A. W: Dox.

(a) Synthesis of a naphthotetrazine from diethyl succinylosuccinate and dicyandiamide. (b) The behavior of benzidine toward selenic and telluric acids. (c) Amino acids and microorganisms: ARTHur W. Dox.

The separation and gravimetric estimation of potassium: S. B. KUZIRIAN.

The action of the amino group on amylolitic enzymes: E. W. Rockwood.

Some of the factors that influence the extraction of gold from ores by the cyanide process: A. W. Hixson.

JAMES H. LEes, Secretary 